\begin{tabular}{|c|c|c|c|c|c|}
\hline \multirow{2}{*}{ LASER WORDS } & PADM & padm'1955 & Dispatch: July 6, 2011 & Journal: PADM & \\
\hline & Journal Name & Manuscript No. & Author Received: & No of pages: 16 & TS: Karthik \\
\hline
\end{tabular}

doi: $10.1111 /$ j.1467-9299.2011.01955.x

\title{
THE FRENCH STATE AND ITS TERRITORIAL CHALLENGES
}

\author{
ALISTAIR COLE
}

This article focuses upon the territorial challenges to the French state. There is a genuine policy puzzle in terms of how to join up separate agencies of the state that is far from unique to France. Introducing new evidence based on interviews with high ranking officials, politicians and representatives of territorial policy communities in 2010, the main body of the article focuses upon the two main territorial reforms of the Sarkozy presidency, the reform of the territorial state, and the local government reform. These cases reveal an original attempt to craft a political discourse based on public sector productivity and state puissance. The article explores the tension between synoptic models of reform, focused on the expectation of rapid and quantifiable macro-level change that suits the short-term returns of the political cycle; and institutionalized processes of meso-level implementation, with different timescales, logics of appropriateness and configurations of actors.

This article presents a theoretically informed, empirically/based account of territorial reform in France under Sarkozy (2007-), encompassing reforms both to the institutional machinery of the state and local government. Why link reform of the state and local government reform? The first obvious response is that there hás been a sustained political enterprise under Sarkozy to join up questions of the territorial state and local government. A state productivity discourse has developed in France that claims to be macro-level and holistic; it involves public organizations as a whole, and imagines sets of coherent responses encompassing state, social security and local government organizations. From a scientific perspective, if there is an important recent literature on decentralization in France (Le Galès 2008; Pasquier 2009; Pinson 2010) and a growing one on state reform at the level of the core executive (Rouban 2007; Bèzes 2009; Eymeri-Douzans and Pierre 2010), much rarer are accounts which frame the state in terms of its overall territorial challenges, encompassing the reform of its own structures as well as the complex relationship with local and regional authorities (Le Lidec 2007). This article proposes to fill this gap. This research endeavour is important and interesting for several reasons. There is a genuine policy puzzle in terms of how to 'join up' separate agencies of the state that is far from unique to France. Peters (2010) identifies the quest for joined up government as a generic movement across European countries, irrespective of state type. There is a more specific intellectual puzzle involving debates around governance; how are broad transnational trends, such as New Public Management, domesticated or obviated in different contexts (Cole 2008; Eymeri-Douzans 2008)? Finally, there is an analytical puzzle about how to evaluate attempts at synoptic reform. Through introducing new empirical data, the article explores the misfit or tension between synoptic models of reform, focused on the expectation of rapid and quantifiable macro-level change that suits the short term returns of the political cycle, and institutionalized processes of meso-level implementation, with different timescales, logics of appropriateness and configurations of actors.

\section{STUDYING THE ‘TWIN FACES’ OF STATE REFORM}

As used in this article, the expression 'twin faces' of state reform in France refers to reforms both of the institutional machinery of the state and of local government. Territorial

Alistair Cole is in the Department of Politics, Cardiff University.

Public Administration Vol. 0, No. 0, 2011 (0-0)

๑ 2011 The Author. Public Administration @ 2011 Blackwell Publishing Ltd, 9600 Garsington Road, Oxford OX4 2DQ,

UK and 350 Main Street, Malden, MA 02148, USA. 


\section{ALISTAIR COLE}

TABLE 1 Sub-national authorities in France, 2011

3

4

\begin{tabular}{|c|c|c|}
\hline Type & Number & Functions \\
\hline Communes & 36,682 & $\begin{array}{l}\text { Varying services, including local plans, building permits, } \\
\text { building and maintenance of primary schools, waste disposal, } \\
\text { first port of administrative call, some welfare services }\end{array}$ \\
\hline $\begin{array}{l}\text { Intercommunal public } \\
\text { corporations (EPCI) }\end{array}$ & 2611 & $\begin{array}{l}\text { Permanent organizations in charge of inter-communal services } \\
\text { such as fire-fighting, waste disposal, transport, economic } \\
\text { development, some housing }\end{array}$ \\
\hline Departmental Councils & 100 & $\begin{array}{l}\text { Social affairs, some secondary education (collèges), road building } \\
\text { and maintenance, minimum income (RSA) }\end{array}$ \\
\hline Regional Councils & 26 & $\begin{array}{l}\text { Economic development, some transport, infrastructure, } \\
\text { State-Region plans, some secondary education (lycées), } \\
\text { training, some health }\end{array}$ \\
\hline Source: & & $\begin{array}{l}\text { Les Collectivités locales en chiffres. 2010. Paris: Ministère de } \\
\text { l'Intérieur. }\end{array}$ \\
\hline
\end{tabular}

administrative decentralization ('déconcentration') preceded political decentralization by two decades. Déconcentration was initially aimed at strengthening the capacity of the French state to undertake regional economic planning, though subsequently it became understood as a form of administrative subsidiarity (Pontier 2010). Administrative decentralization in general, and regional state development in particular, has had great difficulty in becoming a settled part of the French administrative landscape, for reasons that are tied to core features of the French state itself: namely, the vertical control of government ministries over their external services; the career strategies adopted by the professions and the civil service corps; and the rival claims of governmental coordination between distinct levels of state organization, and across government bureaux.

Reforms of the state's own machinery have rarely acknowledged explicitly the need to take into account the logic of decentralization, the other face of territorial reform. As Crozier (1992) has argued, however, decentralization must in part be understood as a reform of the state, insofar as central government strategies for efficient steering involve the delegation of problematic or inflationary policy domains (such as social policy) to lower echelons of public administration. The French Socialist government's decentralization reforms of 1982-83 took place almost two decades after the first 1964 déconcentration reform. These highly complex reforms established 22 elected regional councils, and greatly enhanced the decision-making powers of the 100 departmental councils and of the larger communes. Political decentralization eventually aligned France with the core principles of the Council of Europe's European Charter of Local Autonomy that she finally signed in 2007, namely: the existence of directly elected local authorities; a reference to local authorities in the Constitution; a formal adoption of the principle of subsidiarity; a degree of local financial autonomy and the possibility of contesting central state decisions in the courts (Schondorf-Haubold 2007). Decentralization has made a fundamentally important contribution to the governing of contemporary France. Sub-state actors have acquired new roles, functions and opportunities (table 1). New institutions and forms of territorial capacity building have developed, notably in relation to regional and city governments. The drivers of this process are partisan, economic, institutional, cultural, though only rarely do they involve ethno-territorial identity claims.

Our research object is thus a hybrid one; it involves the state in terms of its overall territorial challenges, encompassing the reform of its own structures as well as the complex 
relationship with local and regional authorities. Our hybrid research object reflects the need to take account of the persistence of a powerful territorial French state, paralleling, partially supervising and occasionally frustrating the activities of local and regional elected authorities. Combining these two traditionally separate analytical fields creates a real added value and allows us to test the reform claims of the Sarkozy presidency.

Three perspectives appear most convincing to offer partial explanations for this linkage between the state and territorial reform under Sarkozy. Our first perspective, drawn mainly from new public management, is that of state productivity. The modern regulatory state seeks to ensure compliance with its directives through standard setting, performance indicators and the close oversight of local government, the welfare sector and semiindependent agencies (Eymeri-Douzans and Pierre 2011). The chief causal factors in such an account are typically economic (the weight of external financial constraints), budgetary (the need for robust performance indicators to control performance) and political (the determination to steer change by a new administration). In the French version of this new managerial turn, the state capacity building project sets out quite explicitly to counteract the consequences of three decades of uneven political and administrative decentralization by imagining new fiscal instruments and performance management regimes. Some observers such as Epstein (2006) have noted a much harsher edge to intergovernmental relations, especially after the stasis of the 2004 decentralization act. Full validation of this hypothesis would require a demonstration that new policy instruments and other forms of central state steering capacity are driving lasting changes in territorial relationships in ways that are broadly consistent with new public management doctrines elsewhere. A weaker version of state productivity would not require such a rigorous empirical demonstration of outcomes (extremely difficult given the temporal scope of our investigation), but would reveal intentions, for which the interview method (used here) is well suited.

Our second perspective, drawn from the insights of historic institutionalism, is that of institutional resilience. Though déconcentration and decentralization in France since the 1980s have modified the locus of local, urban and regional power, the basic architecture of the 'Napoleonic' territorial state (based around departmental prefects, ministerial field services, the communal bloc and the departmental councils in local government) has proved highly resistant to reform. The traditional departmentalist coalition has resisted, or at least sought to control, the alternative dynamic of developing elected regions and new forms of metropolitan governance, arguably more in tune with EU level developments and economic arguments. I have argued elsewhere that France's elected regions have emerged over three decades as significant new institutions, though their impact is rather uneven according to place (Cole 2008). Throughout their existence, however, French regions have had to fight hard for recognition. Thus, the 2003-2004 decentralization reforms, originally conceived ás an overarching set of reforms to strengthen the regions, ultimately transferred important new responsibilities and resources to the departments, supported by the Senate and by key Paris-based ministries. There is a parallel at the level of the state's organization of its own services, where the traditional mode of operation was for the central ministries to prescribe the policy objectives and the means by which these were to be achieved while the (usually departmental) field services were expected to apply these centrally devised directives to their respective local environments (Duran and Thoenig 1996; Jones 2003; de Montricher 2006). Our second perspective has strong elements of path dependency. It is less prone to express itself in terms of an overarching discourse, more inclined to stress the defence of particular institutions or levels of appropriate public administration. 


\section{ALISTAIR COLE}

Our third - favoured - perspective is that of contingent governance. Attempts to describe state reform or decentralization in terms either of precise causal mechanisms and explanatory variables, or by mobilizing overarching meta-narratives, are unlikely to be very convincing. To observe an 'untidy reality' is not simply to engage in empirical description. It is to suggest that variable types of justification and/or causal mechanisms are likely to intervene in the overarching relationship between the French state and its territories. Such observation favours empirically informed individual or aggregate level analysis from a range of distinctive standpoints and logics. From the evidence presented below, and conscious of the need to avoid conceptual inflation, four main types of key variables are identified. Political variables include those of political leadership, party dynamics and the partisan control of institutional venues. Bureaucratic variables are mainly those involving rival bureau-shaping logics and claims at legitimate coordination, involving the Budget and Interior ministries in particular. Professional variables intervene via the strategies of the civil service corps, and competition between professional interests within the state (and local government). Finally, institutional variables can be comprehended both in terms of the development of (sub-national) organizations and as the starting point for building the horizontal and vertical relationships that are at the heart both of the adaptation of inter-governmental relations and the construction of variable territorial 'regimes' that correspond to the politics of place. These four variables are now observed in two linked, yet analytically distinct, cases: the reforms of the territorial state and of local government under Sarkozy.

\section{REFORMING THE TERRITORIAL STATE}

In 2007, the Fillon government launched a General Public Policy Review (Révision Générale des Politiques Publiques - RGPP) with explicit reference to the Canadian Program Review of 1995-1996. The RGPP claims to engage in rethinking the whole state, including the territorial state, understood in terms of the state's operation in the localities, departments and regions, and the efficiency of local and regional authorities. In December 2007, the RGPP steering committee declared that the regional level should steer public policy, while the departmental level should be a level of local service delivery and implementation of central and regional orientations (Interior Ministry 2010). Such a move was presented as a step change in the gradual evolution towards affirming the primacy of the state at the regional level. Following the 2003-2004 decentralization reforms, the decree of 29th April 2004 had proclaimed that the regional prefect 'inspires and coordinates the actions of the departmental prefects'. Moreover, the 30 or so state services with regional offices were regrouped into eight clusters, which mostly prefigured those presented in table 2, though the individual services remained for the moment separate legal entities (Chauvin 2010).

Strengthening the regional state has been one of the constant themes of French postwar territorial administration. The regional prefectures, created in 1964, were initially light, strategic bodies that attempted to coordinate the activities of the much weightier departmental prefectures (Kada 2008; Pontier 2010). They have claimed to provide interministerial leadership of the state, by way of coordinating the 'decentralized' services of government departments; and, more recently, by contractualizing with local and regional authorities and the European Union. The 2010 reform can be read at one level as an attempt to build up the regional prefectures, with the ambition of embedding new forms of central steering and political leadership. The various decrees and circulars published from 2008-2010 identify four core dimensions of this process of regional state capacity 
TABLE 2 The regional state in 2010

\begin{tabular}{|c|c|}
\hline Nomenclature & Functions and services \\
\hline $\begin{array}{l}\text { Regional Prefectures and General } \\
\text { Offices for Regional Affairs (SGAR) }\end{array}$ & $\begin{array}{l}\text { The 'authority' of regional over departmental prefects is } \\
\text { recognized in the decree of } 16 \text { February 2010. The SGAR } \\
\text { obtain new budgetary, management and IT responsibilities } \\
\text { and can henceforth recruit their own staff }\end{array}$ \\
\hline Food, agriculture and forests (DRAAF) & $\begin{array}{l}\text { Merged regional directorates of former Agriculture and Forestry } \\
\text { Ministry with Food }\end{array}$ \\
\hline Cultural Affairs (DRAC) & Largely unchanged \\
\hline $\begin{array}{l}\text { Environment, planning and housing } \\
\text { (DREAL) }\end{array}$ & $\begin{array}{l}\text { Under the mega-Ministry for the Environment, Energy, } \\
\text { Sustainable Development and Maritime Affairs, the DREAL } \\
\text { regroup the three regional directorates for the Environment, } \\
\text { Infrastructure and Housing }\end{array}$ \\
\hline $\begin{array}{l}\text { Firms, competition, consumers, work, } \\
\text { employment and training } \\
\text { (DiRECCTE) }\end{array}$ & $\begin{array}{l}\text { The DiRECCTE unite seven previously separate field services of } \\
\text { two ministries (Work and Economy, Industry and } \\
\text { Employment) including training and lifelong learning, } \\
\text { industry and research, competition and several other } \\
\text { responsibilities }\end{array}$ \\
\hline $\begin{array}{l}\text { Youth, sports and social cohesion } \\
\text { (DRJSCS) }\end{array}$ & $\begin{array}{l}\text { The DRJSCS regroup all activities dealing with social policy, } \\
\text { youth and associative life in one division. They 'lose' health to } \\
\text { the ARS }\end{array}$ \\
\hline Education & 26 Rectorates, depending on the Education Ministry \\
\hline Finance DRFiP & Regional office of the Finance Ministry \\
\hline Regional Health Agencies (ARS) & $\begin{array}{l}\text { New établissements publics to be headed by a director, to lead on } \\
\text { issues of hospitalization, healthcare and medico-sociaux } \\
\text { services }\end{array}$ \\
\hline Source: & $\begin{array}{l}\text { Adapted from 'L'avancement de la réforme de l'administration } \\
\text { territoriale de l'État', RGPP, } 12 \text { mai } 2009 \\
\text { (http:/ / www.rgpp.modernisation.gouv.fr), accessed } 18 \text { May } \\
\text { 2009; 'Quatrième Conseil de Modernisation des Politiques } \\
\text { Publiques', June 2010, RGPP: Paris. }\end{array}$ \\
\hline
\end{tabular}

building: first, to achieve economies of scale through centralizing back-office functions (purchasing, ICT, buildings, maintenance) at the regional level; second, to affirm the formal ascendancy of the regional over the departmental level; third, to reorganize and rationalize the services of the regional and departmental state and place them under the hierarchical authority of the regional (and sometimes departmental) prefect; finally, and probably most importantly, to bring the territorial state into line with the mergers taking place at the central, core executivelevel. For the first time, the decree of 16th February 2010 affirms that the regional prefect has 'authority' over the departmental prefects. Moreover, using the power of revocation ('evocation'), the regional prefect can exercise responsibilities normally reserved for the departmental prefectures for a limited period of time. The departmental prefecture is confirmed by the 7th July 2008 circular in its traditional missions of law and order (control over police and, since 2007, gendarmerie), and the prefectures gain several new functions in terms of immigration and asylum services, and the control of the legality of acts of local authorities. Overall, however, the departmental prefectures complain of losing resources and functions, via the regionalization of back office and support services and the strengthening of the regional level.

The central steering interpretation is supported by the observation that the Fillon government has reorganized the missions of the regional state in a uniform manner across 


\section{ALISTAIR COLE}

French regions. Using the new budgetary law (the LOLF, see below) and the RGPP as the pretext, the reform of the regional state involves creating larger regional services that correspond broadly speaking to the new missions of central government, understood in the language of the budgetary law, the LOLF, which identifies missions and programmes, rather than ministries and divisions. Table 2 briefly presents the new regional state. Of the seven regional directorates, three have not substantially changed. The education ministry remains organized in academies and rectorates; the culture ministry can call on its powerful regional service, the DRAC, and agriculture also has a powerful regional division (DRAAF). Three new regional directorates - the DiRECCTE, the DREAL and the DRJSCS - clearly reflect the priorities of the Sarkozy administration. Each is born out of mergers at the central and regional level, and each also reflects the fusion of administrative corps. These new regional directorates, in the process of being constituted, are crisscrossed by distinct institutional traditions and cultures and by sometimes contradictory interests. Finally, the creation of the regional and departmental financial services (DRFiP in the regions; DDFiP in the departments), reflects the nationwide merger between the previously separate tax assessment and tax collection agencies. The February 2010 decree also affirmed the role of the Regional Administrative Committee (chaired by the regional prefect but bringing together the directors of the seyen new regional services, as well as the head of the new Regional Health Agency and the departmental prefects) as providing a form of collective leadership of the territorial state. All this adds up to an increased steering capacity on behalf of the regional prefects. One interlocutor referred to a return to the 'spirit of 1964', strengthening the regional prefects as the artillery of the heroic state.

The second level concerned by the reform of the territorial state is that of the 96 (mainland) departments. At the departmental level, the principle is not to reflect central missions, but to provide broad services for the population. The two key dimensions are the reduction in the number of services, hence potential points of veto, and strengthening the hierarchical authority of the Prime Minister (above Interior or Finance). In organizational terms, the core innovation is the creation of the interministerial directorates (DDI - the direction départmentale interministérielle) envisaged as somewhere between One Stop Shops and multi-task government offices. A decree of 3rd December 2009 set out the missions of the DDI, summarized in table 3. Unlike the regional services, the DDI are not theoretically responsible in principle to any specific central ministry. Operationally, they are placed under the authority of the departmental prefect, implementing policies determined at the level of Regional Administrative Conference discussed above. A study of the DDI reveals the major problems involved in attempting to reconcile distinct standard operating procedures and to harmonize terms and conditions across the component elements. First, there is a major problem of resources, namely who is responsible for financing these new offices? The fledgling DDI have been financed by several national ministries, which have attempted to impose conditions on 'their' agents and in relation to 'their' buildings or equipment. In relation to staff, the DDI house agents who have very different terms of pay and service depending upon which corps they belong to and which old ministry they served under (Kamel 2009; Debar 2010). As pay and conditions have been averaged upwards, reform of the state machinery is proving expensive. Created formally on 1st January 2010, by mid 2010 the DDI were in crisis; the only solution for buildings and operational expenses was to create a new Programme (in the language of the LOLF) under the authority of the Prime Minister.

The reform of the territorial state was shaped by Claude Guéant, the head of President Sarkozy's staff and, in the words of one interviewee, 'the man who decides everything in 
TABLE 3 The departmental state (metropolitan France)

\begin{tabular}{|c|c|}
\hline Nomenclature & Functions and services \\
\hline Prefectures & $\begin{array}{l}\text { Security, elections, legal control, responsibilities not assumed } \\
\text { by the other departmental divisions. Henceforth control } \\
\text { over the Police and Gendarmerie }\end{array}$ \\
\hline $\begin{array}{l}\text { Interministerial directorate for Territory } \\
\text { (DDT) }\end{array}$ & $\begin{array}{l}\text { Merged directorates of infrastructure, agriculture, forests } \\
\text { and the environment }\end{array}$ \\
\hline $\begin{array}{l}\text { Social cohesion and the protection of } \\
\text { populations (DDCSPP) }\end{array}$ & $\begin{array}{l}\text { Merged directorates for competition, consumer protection, } \\
\text { anti-fraud protection and vetinary services. In large } \\
\text { departments, there are generally separate offices for Social } \\
\text { Cohesion (DDCS) and Protection of the Population (DDPP) }\end{array}$ \\
\hline Education & $\begin{array}{l}\text { The } 96 \text { Academic Inspectors and their services retain control } \\
\text { over primary and some secondary education }\end{array}$ \\
\hline Finances (DDFiP) & The departmental office of the Finance Ministry \\
\hline $\begin{array}{l}\text { Territorial Units of the regional field } \\
\text { services: ARS, DRAC, DiRECCTE }\end{array}$ & $\begin{array}{l}\text { Henceforth under operational control of the departmental } \\
\text { prefects, subject to decisions in the Regional } \\
\text { Administrative Committee }\end{array}$ \\
\hline Source: & $\begin{array}{l}\text { Adapted from 'L'avancement de la réforme de } \\
\text { l'administration territoriale de l'État', Révision Générale } \\
\text { des Politiques Publiques, } 12 \text { mai } 2009 \\
\text { (http: / / www.rgpp.modernisation.gouv.fr), accessed } 18 \\
\text { May 2009; 'Quatrième Conseil de Modernisation des } \\
\text { Politiques Publiques' June 2010, RGPP: Paris. }\end{array}$ \\
\hline
\end{tabular}

this country'. That Guéant was previously a regional prefect obviously had an impact. But this sustained effort at political steering is likely to be a necessary, rather than a sufficient, condition for change. Several intervening variables are likely to act as either countervailing pressures or unpredictable obstacles to the reform goals. The first intervening variable is the territorial one. In small regions where there are only two departments (as in lower Normandy or the Limousin), the departmental prefectures will have far more weight than in larger regions where there are up to eight departments (for example Rhône-Alpes). In larger regions, also, the Regional Council is likely to be a more influential player, able and apt to draw in the regional prefecture into a constructive engagement irrespective of partisan engagement. Pasquier (2010) charts with considerable expertise the role of territorial coalitions between regional state and regional councils that can resist political pressures. The result, in the words of one regional prefect interviewed in 2010, is that prefects need to work hard to establish their core legitimacy amongst their own field officials with respect to central government and in relation to the élus.

Second, in relation to professional dynamics, the key is that regional and departmental prefects remain part of the same corps and usually demonstrate corps loyalty. One regional prefect refused to envisage the relationship with his pairs (important for the sense of corps loyalty) in the departmental prefectures in terms of authority or hierarchy: 'I do not consider my departmental prefect colleagues as people to whom I might give orders, unlike my delegate prefects or my General Secretary'. For the regional prefecture in Brittany, taking over the delivery of services usually assured by the departmental prefectures might conceivably be necessary, but only in very specific areas that related to EU regional policy, new environmental commitments, or clear areas of regional public interest (SGAR 2010). Beyond the prefectures, the unknown variable is how the traditional rivalries between corps will play themselves out in the departmental and regional field 


\section{ALISTAIR COLE}

services. Two examples, drawn from fieldwork in Brittany in the new regional and departmental services in 2010, illustrate likely scenarios. The DREAL brings together the formerly powerful regional services of the equipment ministry (DRE), the industry ministry (DRIRE) and the environment ministry (DIREN). In the case of Brittany, the solution was one of accommodation; the new director was from the DIREN, but associate posts were created for the DRE and the DRIRE. At the departmental level, the DDTM (Ile-et-Vilaine) merged the previously separate divisions of infrastructure, agriculture and environment. One episode demonstrates the persistence of older organizational cultures; the Director gave the example of a former infrastructure bureau in St Malo approving a proposed urban development that was rejected by the local environment bureau. Even though both bureaux were supposed to agree at a local level, they sent up the contested dossier to the director for arbitration (DDTM 2010).

The main obstacle to horizontal leadership relates to the role of the budget and public accounts ministry. As one interlocutor in the Court of Accounts (2005) expressed it very cogently: 'either one defends central steering and vertical coordination, which concentrates power at the central level, or one supports horizontal coordination, which means genuinely giving the prefects hierarchical authority over all central services and agencies in their territories'. One potential lever to allow the regional prefect to impose their authority over the external services is that of the LOLF, the 'new' budgetary law operational since 2006. Under the LOLF, the regional prefects are budget holders (RBOP), formally charged with distributing operational resources to government agencies coming under their hierarchical control. In practice, however, they have 'very limited margins of manoeuvre' and 'virtually no capacity to change the substantive content of policy programmes' (Brittany Regional Prefecture 2010). The budget and public accounts ministry made its presence felt as the core vertical coordinating force. The bulk of resources distributed via the prefectures are ring-fenced for specific services and government agencies. Initially conceived as a tool to join up central government around programmes and missions, the LOLF was not primarily concerned with the interests of local or regional government. The key officials, the Programme Heads (Responsables du Programme), operate in central government departments in Paris and the programmes they administer are national in their logic, allowing little territorial variation.

\section{Summary of reform}

From the above survey, we can draw support for each of our approaches. In favour of the state productivity hypothesis, the strengthening of the regional prefectures is explicitly framed in terms of efficiency gains, notably via the definition and implementation of management targets, greater control and influence over devolved ministerial budgets at the regional level, and oversight over back-office and IT tasks. The strategic plans to be coordinatéd by the regional prefectures must henceforth include provision for the staff working for public corporations (établissements publics) and chambers of commerce, hence bringing these semi-autonomous bodies into the purview of the state administration. Moreover, the official public expenditure targets published as part of the RGPP include not just the state budget, but the larger social security and local government budgets as well; the ambition is clearly stated to exercise tighter control over the vast local government and social security budgets. The reorganizations of the regional and departmental levels of the French state machinery were presented as a product of a synoptic institutional design, conceived in order to limit capture by interest groups and reduce the number of veto points within the administration. The above survey also provided considerable 
evidence of institutional resilience. The government's efforts to make the regional state more coherent ran against key obstacles in the form of vertical and hierarchical logics within the state, the weight of the core institutional feature of the corps, and the rather perverse effects of the budgetary law, the LOLF, which, designed for the central state and its services, has made the coordination of state activity at the territorial level that much more difficult. Strategic state capacity building is likely to run against the constants of bureau-shaping, professional and institutional rivalries. This brief survey of reforms in the local and regional state raises the prospects of likely implementation failure, not least because of the poor linkage with the local government reform that is now considered.

\section{REFORMING AND REFRAMING LOCAL GOVERNMENT IN FRANCE}

The second face of state reform involves inter-governmental relationships and the reform of local government. The 2010, local government reform was presented as part of a logically coherent and joined-up package of reforms designed to modernize the French state. There was purported to be a close linkage between local government reform and the RGPP: the introduction to the main bill refers to it as the second step in the 'modernization of the local structures', coming after the reform of the territorial state undertaken since 2007. Under Sarkozy, decentralization and territorial state reform are both framed in terms of efficiency, cost and joining up the disparate levels of the local and regional public sector. The state is intricately involved in inter-governmental relations in core fields such as structure, finance, standards, norms, contractualization and EU funding, fields that lie outside of the limits of the current exercise. Following the framework of analysis presented above, central-local relations will now be placed within each of our three perspectives of state productivity, institutional resilience and contingent governance which provide the analytical grid for appraising the 2010 Act.

Reversing the order of presentation, the constants of inter-governmental relations are testament to a high degree of institutional resilience. Contemporary France has a rich tapestry of sub-national government, which incorporates directly elected communal, departmental and regional authorities, inter-communal councils, as well as the departmental and regional prefectures, and the field services of the key government ministries and agencies with responsibility for various aspects of territorial management (see tables 1-3, above). The 2010 local government reform was intended in part to address the problem of this institutional mosaic of overlapping structures. Reform-minded governments have attempted to promote local government re-organization in the name of broader principles of territorial equity and economic efficiency. Long before decentralization, the Marcellin law of 1971 had very limited success in its declared objective of merging the 36,500 or so communes and reorganizing them into larger authorities. The 1982-83 and 2003-04 decentralization reforms did not radically alter the highly fragmented structure of French local government. No French government has successfully resolved the problem of the division of responsibilities between the 96 departmental and 22 regional councils in metropolitan France. Such institutional fragmentation should not imply stasis, however. Successive reforms in the 1990s (the Joxe law of 1992, the Voynet and Chevènement laws of 1999) strengthened more joined-up, inter-communal councils through developing inter-communal public corporations with pooled tax revenues (Établissements publics de Co-opération intercommunal - EPCI) throughout urban and much of rural France (Cole and John 2001). In 2010, EPCI cover 95 per cent of the French population. Elected regional councils have also considerably enhanced their prestige and influence. For our analytical 
purposes, the key point is not about identifying winners and losers but observing how endogenous institutional structures are likely to overwhelm any efforts at synoptic state reform. There are too many interests at stake and the state has neither the capacity nor the will to transform existing arrangements.

Consistent with our first perspective, the state now emphasizes its own productivity as the key to future prosperity, an efficiency turn that can be observed in the linked areas of state-region contracts and financial relations. Bringing the state back in to the governance of French localities and regions was the object of the state-region plans introduced in the 1982 planning law (Gaudin 1999; Burnham 2009). Consistent with the state productivity thesis, since 2003, there has been a movement away from the language of contractualization. The state-region plans have been relabelled as state-region projects, with much stricter national criteria governing their operation and less room for adaptation to local and regional circumstances. In the 2007-2013 round of state-region projects, the French state was far more prescriptive in terms of the types of field that could enter into agreements, defining the broad priorities themselves based on France's EU priorities (competitiveness, sustainable development and social and territorial cohesion) (Pontier 2007; Lerousseau 2008). Controlling local government finance is the other central feature of the state's close involvement in localities. Since 2004, the politicization of central-local relations has spilled over into disputes about local taxation. Largely run by the Left, local authorities have been accused by the governing centre-right (UMP) government of financial profligacy. In a move reminiscent of Thatcher in the 1980s, in 2009 the Fillon government announced what amounts to a central cap on the business rates charged by local authorities. The new provision was rushed through parliament in the 2010 budget, before any consideration had been given to the broader local government reform (Hertzog 2010). The political objective was clear: to use the argument of financial necessity to override entrenched interests and centralize control over one of the main instruments of local taxation.

The above evidence is suggestive of a coherent managerial turn. Consistent with our contingent governance thesis, however, one must point to clear divisions within the state, even in the technical field of budgetary policy. From the perspective of the interior ministry, the most successful local government reforms, especially the 1999 Chevènement law, have naturally required financial inducements to encourage communes to cooperate. From the perspective of the budget and public accounts ministry, however, institutional duplication and local government capacity building has had an unacceptable financial cost. The increase of staff numbers in the EPCI in particular has raised fiscal sustainability concerns (Finance Ministry 2010). Even more than divisions within the state, the key dimension of contingent governance is that of institutional and party political dynamics. There has traditionally been no simple left-right cleavage in relation to decentralization; supporters and opponents of more decentralization could be identified on left and right. The gradual conquest of a majority of France's regions, departments and large towns and cities by the Left, combined with successive victories in decisive national elections by the Right, introduced a partisan dimension that became increasingly pronounced. This sharper party political cleavage provided the backdrop against which President Sarkozy (2007-) undertook to reform the French state and its territories.

The local government reform, 2010

The set of laws and decrees that became known as the local government reform of 2010 were loosely based on the findings of the Balladur Commission of 2009, itself the latest 
in a string of reports under Sarkozy into core challenges faced by local authorities and the state. The Balladur Commission (2009) advocated a radical overhaul of the structures, functions, legal principles and public finances of French local and regional government, as well as a more joined up approach to intergovernmental relations. Though loosely based on Balladur's report, the 2010 reform fell short of the report's ambitious recommendations (Nemery 2010).

The local government reform of 2010 was ostensibly designed to rationalize competencies and avoid duplication between layers. To enhance transparency and efficiency, Balladur had called for a reduction in the number of regions from 22 to 15, encouraged the merging of departments into larger entities and advocated that directly elected intercommunal councils (EPCI) should cover the whole French territory by 2014. The main 2010 law extends the operation of the intercommunal councils (EPCI) to all of France by 2014, a 'consensual measure' in the words of the Socialist rapporteur in the Senate, though it falls short of their direct election (Sueur 2010). As one interlocutor put it, these technical provisions concerning inter-communal councils represented 80 per cent of the bill. In practice, as table 1 demonstrates, on 1 January 2010, there were already 2611 EPCI, which regrouped 34,774 communes (95 per cent of the total) and covered 92.2 per cent of the overall population. The EPCI have been criticized from the basic democratic standpoint that these non directly elected bodies are responsible for the fastest growing part of local expenditure, yet they are subject to no democratic scrutiny. The 2010 reform acknowledged these democratic and fiscal concerns, but abandoned proposals for the direct election of EPCI under pressure from the communal bloc (see below). There was less consensus in relation to other proposals. Early briefings that the departments might be abolished were silenced once Sarkozy made known his opposition (DGCL 2010). The suggestion that some regions might be merged against their will was abandoned. Finally, far from being the single tier unitary authorities envisaged by Balladur, the 12 new Metropolitan Councils were reduced in the government bill to being voluntary public corporations (hence not fully fledged local authorities) to be set up on the basis of agreements between communes, proposals which were then diluted further by the Senate.

Consistent with the broad philosophy of the RGPP, the Balladur report emphasized the importance of clarifying service delivery responsibilities across levels of local government to avoid duplication. In practice, however, the 2010 reform was highly constrained by the provisions of the 2003 constitutional reform for the 'free administration of local authorities' and the interpretation by the Senate that no local authority can exercise authority (tutelle) over any other. By refusing any hierarchy between local authorities, the 2004 decentralization Act had checked the emergence of the region as the key federating body and, in the process, undermined the declared objective of strengthening the state at the regional level (Cours des comptes 2009). By mid-way through the 2010 bill's second reading, the Fillon government effectively abandoned the idea of introducing a far-reaching overhaul and rationalization of local government competencies. Instead, an amendment stipulated that, in each region, the distribution of service delivery responsibilities will be agreed in a signed contract between the regional and departmental councils, to be approved, moreover, by the regional prefect. Rather as in 2004, in 2010 the idea of the lead authority (chef de file) was emptied of its substance. This reversal ought to be attributed to the combined influence of the bloc communal (the communes, many intercommunal syndicates and their professional associations) coupled with the determination of the second chamber, the Senate, to represent the interests of rural and 
small town France. The resilience of the communal bloc became clear as the 2010 territorial reform progressed through the two house of the French parliament in 2010.

The most controversial element of the 2010 territorial reform was the new territorial councillor, a locally elected politician who, from 2014 onwards, will combine the existing roles of departmental and regional councillor. This institutional innovation is presented by the law's framers as a response to the calls for clarification between the roles of the regions and the departments. The argument in favour is that a single councillor will strengthen the cohesion of the 'department-region' couple, with a view to producing a harmonization between these two levels of local authority, hence addressing the problem of duplication (DGCL 2010). Two readings of this institutional innovation were expressed in interviews. One involves the expectation that the department will eventually wither away, with the regional councils gradually taking over the responsibilities of the departments. A more widespread sentiment took exactly the opposite position; namely, that the regions will most likely be captured by departmental interests. As elections for the new councillors will take place on the basis of single member geographical constituencies, the territorial interests of the departments will prevail over the larger region. The territorialized partisan cleavage really came to the fore under Sarkozy, with the controversy over the new territorial councillor, and the associated widespread suspicions of gerrymandering and institutional engineering.

Was this a coherent joined-up approach or a set of incremental adjustments? Even those involved in writing the 2010 Act did not lend much credence to the 'joinedup' hypothesis. In the opinion of one interlocutor in the interior ministry, the RGPP was a budgetary process associated with cost-cutting (and driven by the budget and public accounts ministry), hence the local government reform had little interest in being presented as part of RGPP. The familiar narrative of state reform as a contest between the rival bureaucratic actors with a stake in governmental coordination - interior, budget, Matignon - resurfaces (Bezes 2009). The local government reform is best interpreted as a series of incremental adjustments. It became clear, in the course of the passage of the bill through parliament, that there was a basic capacity-expectations gap. The Balladur report called for an overhaul and clarification of the division of competencies between levels of local authority. In the event, the Fillon government abandoned the idea of a separate piece of legislation 'because there would have been no consensus on the issue either between the ministries, or the local government associations' (DGCL 2010). Strikingly, the decision not to proceed with a comprehensive overhaul of competencies was justified in interviews in terms of the complexity of the exercise; the government had neither the time nor the capacity to undertake this (DGCL 2010). The reforms did not fundamentally resolve, or even address the problem of path dependent institutions. Ultimately, the local government reform added still further to the institutional complexity that provided the raison d'être for the reform itself.

The 2010 territorial reform represented a good example of a form of 'contingent governance'. The reform was strictly bounded by the constitutional principle of the free administration of local authorities. The proposed reform was also modified in relation to provisions whereby the intercommunal bodies could deliver services on behalf of local councils in order to comply with advice from the European Commission (Marcou 2010). The importance of partisan and institutional rivalries emerges clearly from this account. This element of partisan competition had an impact upon the eventual outcomes of the 2004 reform; why strengthen the regions if they were to be controlled by the opposition parties? Somewhat paradoxically, the politicization of territorial relations has been mediated by the 
effect of institutions. The constitutional reform of 2008 has introduced new dynamics that can cut across party loyalty and make expected governmental outcomes less certain. The parliamentary committees, both in the National Assembly and the Senate, have emerged as powerful players. The UMP-led government was forced into a series of concessions to the parties forming part of the presidential majority (including UMP). The precise interplay between these bureaucratic, partisan and institutional rivalries better explained the outcome of the 2010 territorial reform than the narrative of state productivity.

\section{THE FRENCH STATE AND ITS TERRITORIES}

The cases considered in this article reveal an original attempt to combine a political discourse based on public sector productivity and state puissance, and to apply a rational policy-making model to the reform of the territorial state and the 2010 reform of local and regional authorities. As an internal reform of the state's own machinery, the reform of the territorial state was entirely implemented by secondary legislation (circulars and decrees). There was virtually no public negotiation, and what opposition emerged was expressed in terms of President Sarkozy versus the traditional corps of the state. Whether the reform of the territorial state would succeed or not was uncertain. Indeed, there was ample evidence of obstacles in the form of hierarchical, professional and rival bureaushaping logics within the existing state, as well as the perverse effects of the LOLF. But the policy review was far-reaching in its scope and the degree of formal institutional change achieved was impressive, whether understood in terms of the merging of corps, the fusion of departmental and regional field services, or the creation of mega-ministries at the level of the core executive itself. In contrast, the local government reform required complex and detailed legislation and had to be steered through a divided presidential majority and accommodate an affirmative second chamber, the Senate, with a specific constitutional responsibility for local government. Through passing a number of important amendments, the Senate confirmed its reputation as a resolute defender of the 36,000 or so communes, a sceptic towards forms of regional and metropolitan governance, and a powerful force in favour of the status quo. In the case of the local government reform, there were more complex sets of interests, institutional venues and veto points; but above all the government effectively abandoned any serious attempt radically to reshape the institutional map in the face of so many well-entrenched interests. Sarkozy was less personally committed to local government reform and anxious to compromise in advance of the 2010 senatorial, 2011 cantonal and 2012 presidential elections.

To conclude, the three perspectives presented in the introductory section each elucidate aspects of state reform. They behave as one might expect them to do. State productivity, in the form of the RGPP, provided an overarching frame that articulated the intentions of reform-minded governors. The Fillon government's official position was that the territorial state and local government reforms were both part of a logically coherent and joined-up package designed to modernize the French state. This holistic approach is consistent with broader questions of institutional design; rather than multiply single purpose agencies, or introduce market or quasi-market principles, the policy fashion under Sarkozy has been to create mega-ministries at the centre in a more traditional attempt to join up state activity and provide state steering. An NPM-style discourse is consistent with varying institutional or instrumental choices.

In both cases there was evidence of institutional resilience. If one goal of the local government reform was to reduce institutional density and layering, then it ought to be 
regarded as a lost opportunity. Though both reforms claimed a link with the RGPP, taken together they suffered from a lack of coherence, even a basic inconsistency. Two examples illustrate this. First, the Balladur report proposed that, where state responsibilities had been transferred to local and regional authorities, the state field services ought to be suppressed, a cost-cutting and potentially far-reaching measure. But there was no further reference to this in the bill. Second, the territorial reform of the state, piloted by Sarkozy and the chief of his presidential staff Guéant (himself a regional prefect), was intended unambiguously to strengthen the regional level. And yet, the local government reform, if anything, reinforced the supervisory role of the departmental prefect (who now has a key role in approving how inter-communal councils are to be organized within a department and which services they deliver [Marcou 2010]) and refused to grant a leadership role for the regional councils which might benefit political opponents.

State reform, as described throughout the article, has elements of a 'garbage can' logic. The chances of reform appear rather dependent on the particular mix of political, bureaushaping, institutional and professional dynamics, as well as the nature and timescale of the reform undertaken. Far from the abstract meta-narratives (state productivity), or static causal mechanisms (path dependency), the approach adopted allows a more realistic strategy to uncover the political, bureau-shaping, professional and institutional dynamics that mediate the relationship between the French state and its territories. Taking account of these four dimensions, the core question thereby becomes reformulated into a hybrid one: when and how do political, bureau-shaping, professional and institutional dynamics matter? Robust political leadership is required to drive reform that challenges institutional inertia; its chances of success appear correlated to timescale and intensity (Elgie 1993; Burnham 2009). Presidential power is most effective in France when there is active presidential involvement in steering, as in the case of the early RGPP. In the case of Sarkozy, the partisan dimension also emerges clearly as a driver of, and an obstacle to, reform. The RGPP was part of a clear presidential mandate and accepted as such within the governing UMP. The local government reform involved cross-cutting partisan and institutional interests: it was modified as a result of internal opposition within the governing majority, but it was also carefully designed to secure maximum political advantage for the President's party.

Although less visible than these macro-political considerations, more routine bureaushaping logics are continually present. Both cases revealed rivalries within the state based on the rival strategies of central divisions that filter down to the departmental and regional levels. In both cases, these turrf wars mainly involved the budget and the interior ministries. They were strengthened by professional dynamics, though the significance of the corps appears less visible at the regional and local levels and the research uncovered some evidence of internal divisions, especially in the prefectoral corps. Finally, the institutional variable was a key one for contrasting the two cases: the RGPP was mainly confined to internal state processes, while the local government reform became enmeshed in the complex interactions between interests (especially the local government associations), and formal and informal institutions. In sum, the political leadership steered reforms that were partially embraced and partially resisted by bureaucratic interests. Professional influences appeared somewhat on the defensive, testament to the changing nature of elites under Sarkozy and the disorientation of the corps (Gervais 2010). Partisan and institutional influences helped to shape the eventual outcome of the two cases considered.

Some more generic conclusions might also be drawn. In both cases, reform was conditioned in precise ways by the consequences of past decisions. The reform of 
the territorial state ran against the obstacle (for the regional prefects, at least) of the budgetary law, the LOLF, which operated against 'joining up' government on a horizontal basis. The local government reform was bounded by previous constitutional decisions taken in relation to the principle of the free administration of local authorities. These examples also contribute to our understanding of contrasting timescales. While the political temporal horizon requires immediate returns (hence encourages transformational styles of leadership, others things being equal), the administrative cycle and timescale is more distant. As one interlocutor stated, officials were still working out how to implement previous far-reaching reforms such as the LOLF of 2001 and Act 2 of decentralization in 2003-2004. Reforms of the state machinery and local government might be driven by high level political pressures, but they are implemented by public servants over a period of several years. Holistic and far-reaching reforms, such as the RGPP and the local government reform, are equalled in the scope of their ambition by the magnitude of the unintended consequences of their implementation.

\section{ACKNOWLEDGEMENT}

I would like to thank Romain Pasquier, Christian de Visscher, and Patrick le Galès for reading this article and making good comments for revision. Above all my thanks go to the anonymous reviewers, whose input was invaluable, and to the editors of Public Administration.

\section{REFERENCES}

Assemblée des Communautés de France. 2010. Interview Mây 2010.

Assemblée des Communautés Urbaines de France. 2010. Interview May 2010.

Association des Régions de France. 2010. Interview May 2010.

Bezes, P. 2009. Réinventer l'Etat. Les réformes de l'administration française. Paris: PUF.

Burnham, J. 2009. Politicians, Bureaucrats and Leadership in Organisations. Lessons from Regional Planning in France. Basingstoke: Palgrave.

Chauvin, F. 2010. 'La Nouvelle administration régionale de l’Etat', Actualité Juridique - Droit Administratif, 14, 831.

Chevallier, J. 2003. Le Service Public. Paris: PUF.

Cole, A. 2006. Beyond Devolution and Decentralisation. Building Regional Capacity in Wales and Brittany. Manchester: Manchester University Press.

Cole, A. 2008. Governing and Governance in France. Cambridge: Cambridge University Press.

Cole, A. and P. John. 2001. Local Governance in England and France. London: Routledge.

Comité pour la Réforme des collectivités territoriales. 2009. 'Il est temps de décider', Paris.

Cour des Comptes. 2009. La conduite par l'Etat de la decentralisation. Paris: Cour des comptes, p. 167.

Crozier, M. 1992. 'La Décentralisation est-elle une réforme de l'Etat?', Pouvoirs locaux, 12, 130-4.

de Montricher, N. 2006. 'L 'Administration territoriale de la République: une idée en quête de réalité', in F. Dreyfus and J.-M. Eymeri (eds), Science Politique de l'Administration. Paris: Economica, pp. 135-52.

Debar, A. 2010. 'La Gestion des hommes dans l'Administration territoriale de l'État: Entre bricolage gestionnaire et travail sur le sens', Revue Française d'Administration Publique, 132, 757-70.

Délégation Interministérielle à l'Action et à la Compétitivité du Territoire. 2007. Interview May 2007.

Direction de la Réforme budgétaire. 2005. Interview July 2005.

Direction départementale des Territoires et de la Mer, Ile-et-Vilaine. 2010. Interview October 2010.

Direction du Budget. 2010. Interview May 2010.

Direction général des collectivités locales (DGCL). 2010. Interviews May 2010.

Direction générale de l'Administration et de la fonction publique (DGAFP). 2010. Interview May 2010.

Direction générale de la Modernisation de l'Etat (DGME). 2010. Interviews May and August 2010.

Direction régionale de l'environnement, de l'aménagement et du logement (DREAL), Brittany. 2010. Interview October 2010.

Duran, P. and J.-C. Thoenig. 1996. 'L'Etat et la gestion publique territoriale', Revue Française de Science Politique, 45, 4, 580-622.

Elgie, R. 1993. The French Prime Minister. London: Macmillan. 


\section{ALISTAIR COLE}

Epstein, R. 2006. 'Des contractualisations territoriales aux appels à projets', in J.-C. Nemery (ed.), Les pôles de compétitivité dans le système français et européen. Paris: L'Harmattan, pp. 81-90.

Eymeri-Douzans, J.-M. 2008. 'Les réformes administratives en Europe: Logiques managérialistes globales, acclimatations locales', Pyramides, 15, 11, 71-93.

Eymeri-Douzans, J.-M. and J. Pierre (eds). 2010. Administrative Reforms and Democratic Governance. London: Routledge.

Gaudin, J.-P. 1999. Gouverner par Contrat. L'Action publique en question. Paris: Presses de Sciences Po.

Gervais, J. 2010. 'Fusionner pour durer? Grands corps techniques et restructurations administratives en France', International Review of Administrative Sciences, 76, 3, 425-41.

Hertzog, R. 2010. 'Collectivités territoriales: La réforme sans l'argent, impossible ou indispensable?', in J.-C. Nemery (ed.), Quelles Perspectives pour la Réforme territorial. Paris: L’Harmattan, pp. 91-106.

Jones, G.W. 2003. 'The Effects of the 1989-1997 Administrative Reforms on the Ministerial Field Services', PhD dissertation, Southampton Institute/Nottingham Trent University.

Kada. N. 2008. 'La Régionalisation des préfectures', Pouvoirs Locaux, 77, November, 29-34.

Kamel, W. 2009. 'Le future visage de l’État dans le département: Une organisation resserrée et modulaire des services déconcentrés', Revue Francaise d'administration publique, 131, 595-600.

Le Galès, P. 2008. 'Territorial Politics in France: le calme avant la tempête?', in A. Cole, P. Le Galès and J. Levy (eds), Developments in French Politics 4. Basingstoke: Palgrave, pp. 235-60.

Le Lidec, P. 2007. 'Le jeu du compromis. L'État et les collectivités territoriales dans la decentralisation en France', Revue française d'administration publique, 121-2, 111-30.

Lerousseau, N. (ed.). 2008. La Décentralisation à la croisée des chemins. Paris: L'Harmattan.

Loughlin, J. 2007. Sub-National Government: The French Experience. Basingstoke: Palgrave.

Marcou, G. 2010. 'La réforme territoriale: ambition et défaut de perspective', Actualité Juridique - Droit Administratif, 2, 2-21.

Ministère de l'Intérieur. 2010. L'Etat en mouvement. Directive nationale d'orientation des prefectures. Paris, p. 78.

Nemery, J.-C. (ed.). 2010. Quelles Perspectives pour la Réforme territorial. Paris: L'Harmattan.

Pasquier, R. 2009. 'The Europeanisation of French Regions', French Politics, 7, 2, 123-44.

Pasquier, R. 2010. Le Pouvoir Régional. Mobilisations, décentralisation et gouvernance en France. Paris: Institut d'Etudes Politiques. Peters, G. 2010. The Politics of Bureaucracy, 6th edn. London: Routledge.

Pinson, G. 2010. 'France', in M.J. Goldsmith and E. Page (eds), Changing Government Relations in Europe. From Localism to Intergovernmentalism. London: Routledge, pp. 68-87.

Pontier, J.-M. 2007. 'Les contrats de projet Etat-régions 2007-2013', Revue administrative, 359, 523-34.

Pontier, J.-M. 2010. 'Le nouveau préfet', Actualité Juridique - Droit Administratif, 14, 819-26.

Préfecture de Région Bretagne. 2010. Interview August 2010.

Rouban, L. 2007. 'Public Management and Politics: Senior Bureaucrats in France', Public Administration, 85, 2, 474-501.

Schondorf-Haubold, B. 2007. 'L'émergence d'un droit commun de l'autonomie territoriale en Europe', Revue française d'administration publique, 121-2, 203-18.

Secrétariat d'État aux collectivités territoriales. 2010. Interview May 2010.

Secrétariat général des Affaires Régionales de la Région Bretagne (SGAR-Bretagne). 2010. Interview July 2010.

Sueur, J.-P. 2010. Interview September 2010, Senate.

Date received 25 September 2009. Date accepted 6 December 2010. 


\section{USING E-ANNOTATION TOOLS FOR ELECTRONIC PROOF CORRECTION}

\section{Required Software}

Adobe Acrobat Professional or Acrobat Reader (version 7.0 or above) is required to e-annotate PDFs.

Acrobat 8 Reader is a free download: http://www. adobe.com/products/acrobat/readstep2.html

Once you have Acrobat Reader 8 on your PC and open the proof, you will see the Commenting Toolbar (if it does not appear automatically go to Tools $>$ Commenting $>$ Commenting Toolbar). The Commenting Toolbar looks like this:

\begin{tabular}{|c|c|}
\hline Commenting & $\underline{x}$ \\
\hline 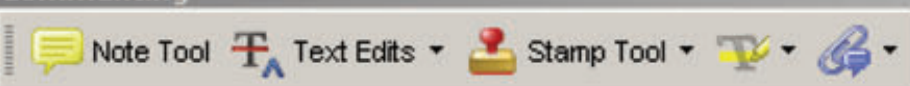 & Show - Send Comments \\
\hline
\end{tabular}

\section{Note Tool - For making notes at specific points in the text}

Marks a point on the paper where a note or question needs to be addressed.

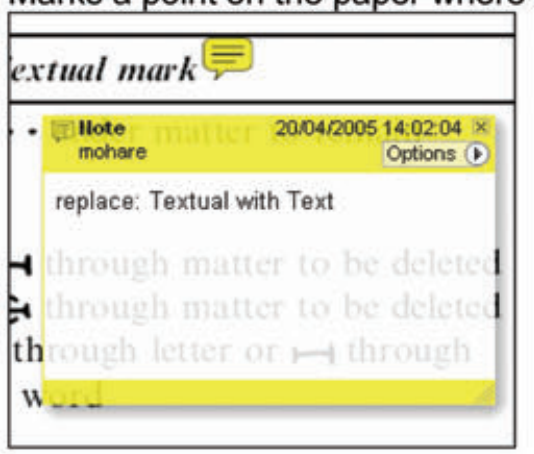

\section{How to use it:}

1. Right click into area of either inserted text or relevance to note

2. Select Add Note and a yellow speech bubble symbol and text box will appear

3. Type comment into the text box

4. Click the $X$ in the top right hand corner of the note box to close.

\section{Replacement text tool - For deleting one word/section of text and replacing it}

Strikes red line through text and opens up a replacement text box.

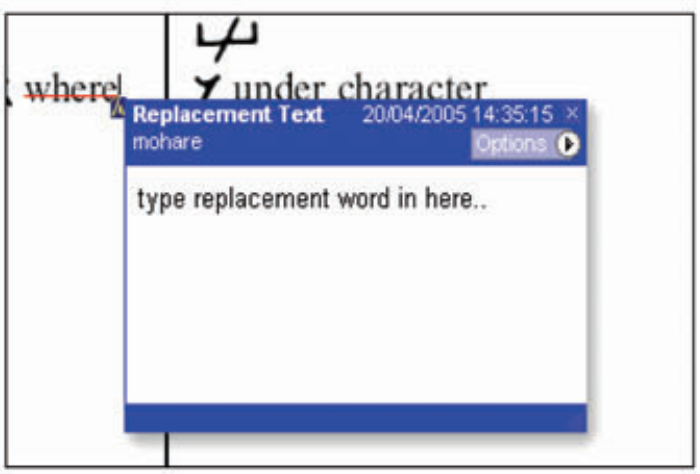
How to use it:
1. Select cursor from toolbar
2. Highlight word or sentence
3. Right click
4. Select Replace Text (Comment) option
5. Type replacement text in blue box
6. Click outside of the blue box to close

Cross out text tool - For deleting text when there is nothing to replace selection Strikes through text in a red line.

\begin{tabular}{|l|}
\hline substitute part of one or \\
more word(s) \\
Change to italies \\
Change to capitals \\
Change to small capitals \\
\hline
\end{tabular}
How to use it:
1. Select cursor from toolbar
2. Highlight word or sentence
3. Right click
4. Select Cross Out Text

\section{Approved tool - For approving a proof and that no corrections at all are required.}

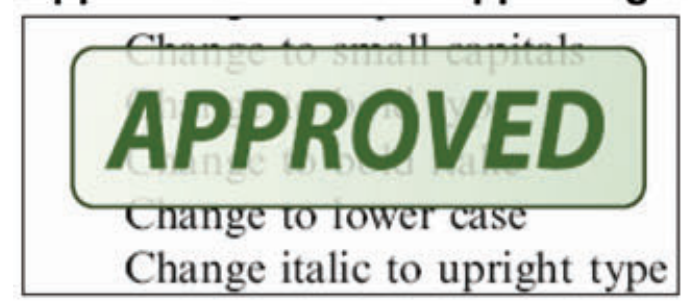

Page 1 of 2

\section{How to use it:}

1. Click on the Stamp Tool in the toolbar

2. Select the Approved rubber stamp from the 'standard business' selection

3. Click on the text where you want to rubber stamp to appear (usually first page) 
Highlight tool - For highlighting selection that should be changed to bold or italic. Highlights text in yellow and opens up a text box.

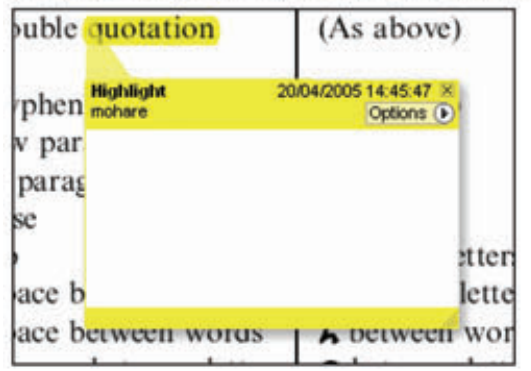

\section{How to use it:}

1. Select Highlighter Tool from the commenting toolbar

2. Highlight the desired text

3. Add a note detailing the required change

Attach File Tool - For inserting large amounts of text or replacement figures as a files. Inserts symbol and speech bubble where a file has been inserted.

\begin{tabular}{|l|} 
matter to be changed \\
matter tg be clanged \\
matter to be changed \\
matter to be changed
\end{tabular}

\section{How to use it:}

1. Click on paperclip icon in the commenting toolbar

2. Click where you want to insert the attachment

3. Select the saved file from your PC/network

4. Select appearance of icon (paperclip, graph, attachment or tag) and close

\section{Pencil tool - For circling parts of figures or making freeform marks}

Creates freeform shapes with a pencil tool. Particularly with graphics within the proof it may be useful to use the Drawing Markups toolbar. These tools allow you to draw circles, lines and comment on these marks.

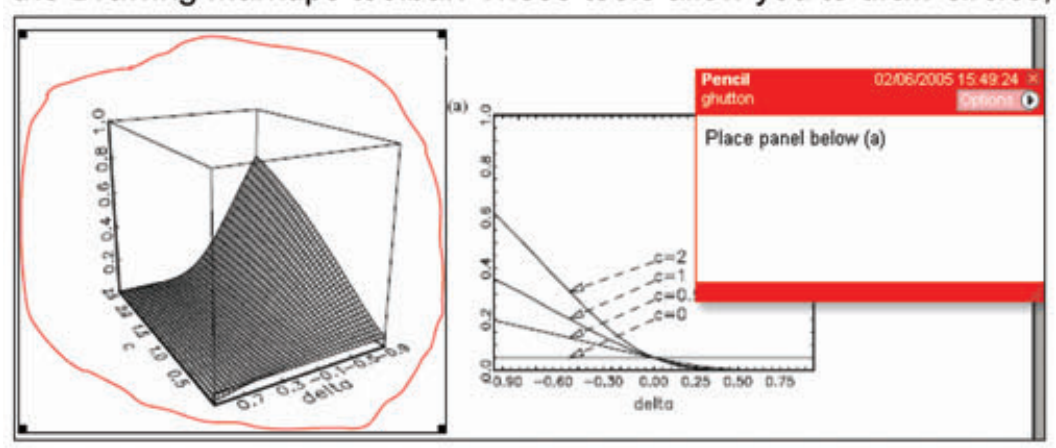

How to use it:

1. Select Tools $>$ Drawing Markups $>$ Pencil Tool

2. Draw with the cursor

3. Multiple pieces of pencil annotation can be grouped together

4. Once finished, move the cursor over the shape until an arrowhead appears and right click

5. Select Open Pop-Up Note and type in a details of required change

6. Click the $\mathrm{X}$ in the top right hand corner of the note box to close.

\section{Help}

For further information on how to annotate proofs click on the Help button to activate a list of instructions:

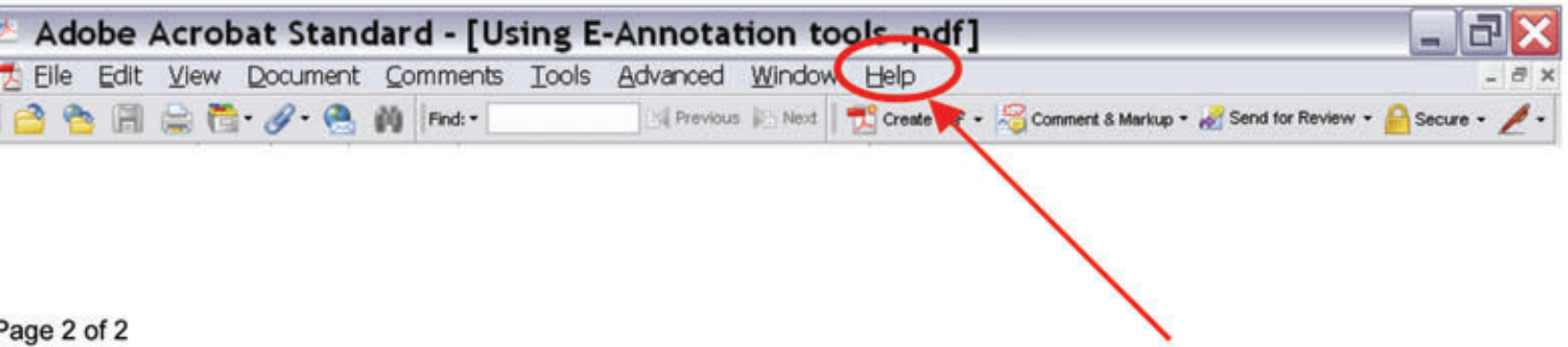

